\title{
Exploring the Principles of Andragogy: Some Comparison of University and Community College Learning Experiences*
}

\author{
Y.L. JACK LAM, Ph.D.**
}

\section{ABSTRACT}

The learning experiences of 740 University and Community College students from various programs have been examined from the andragogical perspective. Through the analysis of fifteen aspects of the learning process, discrepancies of real and expected learning experiences were traced to institutional, program and individual characteristics. While the principles of andragogy remain valid as instructional guidelines for postsecondary institutions, the present findings draw attention to the importance of intellectual maturity as a basic source for organizing meaningful learning for adult students.

\section{RÉSUMÉ}

Les expériences de 740 étudiants en divers domaines et de niveaux soit universitaire, soit collégial ont été examinées sous un angle andragogique. De par l'analyse, sous quinze aspects du progrès d'apprentissage, il ressort des divergences réelles et anticipées attribuables aux caractéristiques individuelles des institutions et des programmes. Bien que les principes de l'andragogie demeurent valides comme indicateurs du niveau d'instruction dans les institutions d'enseignement postsecondaire, les résultats de cette étude attirent l'attention sur l'importance d'une maturité intellectuelle comme élément essentiel d'un enseignement adéquat conçu pour les étudiants adultes.

\section{INTRODUCTION}

Since 1950 , activated by an interest in life-span developmental psychology, a number of key individuals in adult education, notably Kidd (1959), Houle (1961), Verner \& Booth (1964), Tough (1971) and Knowles (1950, 1973), have investigated various aspects of adult learning with a view to constructing a theory from which might be developed a set of explicit principles for guiding the learning process of adults at every stage. Even, although the teaching of adults has been the

* Acknowledgement is made to my colleague, Dr. C. Carbno, for his helpful critiques and comments in the preparation of the manuscript.

** Professor, Faculty of Education, Brandon University 
function of colleges and universities ever since their existence, the formulation of a theory of adult learning must be considered as of relatively recent origin (Knowles, 1978).

Basically, andragogy, as a theory of adult learning, is based on two premises: (1) that adult learners have a clear perspective of their needs and (2) that meaningful learning occurs maximally for adults only when their life experiences can be accommodated in the instruction they receive. The principles of such a theory have been slow in coming to light.

In higher education, the adoption of the principles of andragogy has been sluggish. For one thing, the andragogical perspective demands a marked departure from the traditional "subject-centered" and "teacher-structured" curriculum and methodology of teaching adults. Critics of the traditional approach, who, upon seeing that "the flame of learning did not burn brightly in most (college) teachers and apparently was seldom fanned in students," called for faculty members that were prepared and willing to embrace andragogy as the way (Eckert, 1973), were almost alone in their enthusiasm.

For another thing, there has been confusion among leaders in the movement as to the exact nature of andragogy. Is andragogy a learning theory (Knowles, 1978)? From Gage's perspective on the relationship of theories of learning and theories of teaching, andragogy is more a theory of teaching than it is a theory of learning (Gage, 1972). Is it a philosophical position (McKenzie, 1977), a political reality (Carlson, 1979), or, set of hypotheses to be tested?

Elias (1979) pointed out that the basic cause for the confusion was that andragogy "has been a helpful slogan in the adult education movement." Be that as it may, the status of andragogy as a theory remains unclear and the practitioner needs to know, as Cross (1981) pointed out, how to help the individual adult learn. What is needed, then, is the validation of andragogical principles on the basis of empirical evidence.

\section{THE STUDY}

The problem. The purpose of the study herein described was to test the validity of andragogy as a theory in the context of a university and community college setting. For this purpose, the responses of university and community college students to the items of a questionnaire specifically designed for the purpose of the study were examined on the assumption that andragogy could be validated on the basis of its application to their learning.

Specifically, the study focused on two types of learning experiences described in the literature on adult education: (1) the ideal or desired learning experiences that the learners hoped to have and (2) the actual or real learning experiences that they did have. The responses to the items of the questionnaire dealing with the ideal learning experiences were sought on the assumption that such responses would help determine the extent to which andragogical principles truly represent the desired instructional structure and process for these learners, and the degree to 
which "gaps" existed between the desired and actual learning experiences of these learners would reveal how much teaching at the postsecondary education has been in line with these principles.

The general question then which helped focus the present investigation was: "Are there any discrepancies in the actual and ideal learning experiences of the students at the postsecondary institutions?" The search for answers to this question necessitated a closer scrutiny of all possible sources - institutional, program and individual - that might lead to "discrepancies."

In view of the growing empirical evidence that points to the close relationship between attitude and achievement or behaviors (e.g. Cole and Glass, 1977; Lam, 1982), the identification of the extent of the gap should be of particular interest to adult educators in the universities and community colleges as well as to adult instruction at other levels as well.

The principles. An extensive search of literature in adult education yielded some fifteen conventional andragogical principles that seemed to have universal implications for the learning process. These principles are shown in relation to specific aspects of instruction in Table I.

The questionnaire. To secure data for the present study, a questionnaire encompassing the 15 andragogical principles, specified in the earlier section, was constructed. Each principle was associated with two five-point Likert-type items. One solicited the degrees of actual classroom learning experiences that complied with each principle. Another measured the extent that students expected their learning experience would comply with the principles.

Additional background information pertaining to students' age, sex, level of formal education, and program/area of specialization was also sought.

Sample. So that participants in the study represented all the major programs in postsecondary institutions, a stratified random sampling of students attending a university and a community college in Western Manitoba was undertaken.

In total, 1000 questionnaires were distributed: 500 to the University and 500 to the Community College. Some 366 questionnaires, a rate of return of $73 \%$ from the University sample and 374 or $75 \%$ from the Community College were secured for data analysis.

Participating in this study, there were 142 students from the Faculty of Arts (mostly from the first year classes). The average age was 18 , with an equal proportion of males and females. There were 50 Science Faculty students. These students were on an average two years older than the Arts students. However, their academic backgrounds and gender were comparable. From the Faculty of Education, there were 84 participants. These students were on the average 20 years of age, mostly female and of an average level of education one year senior to Arts and Science students. There were 31 participants from the School of Music, with an average age of 19 . Most were female with an average of two years of university education. There were 27 from the Non-Credit programs. Older in age than other groups (i.e. 28), these students were mostly female having an average of one year 
ASPECTS OF INSTRUCTION AND RELATED ANDRAGOGICAL PRINCIPLES

ASPECTS OF INSTRUCTION

(A) Planning

(B) Setting

(C) Content and Resource Materials

(D) General Approaches to Instruction

(E) Attitude of the Instructor

(F) Progress

(G) Pattern of Learning

(H) Evaluation
RELATED ANORAGOGICAL PRINCIPLES

(1) student.s and teachers should be involved in a mutual process of formulating learning objectives and that the teacher should share his/her thinking about opt fons available in the design of learning experience (Knowles, 1980)

(2) the learning experiences must take into consideration participants' background, level of experience, perspective, and interest (London, 1960).

(3) learning should take place in a climate of openness, mutual trust and respect (Knowles, 1980).

(4) learning should be life-centred and not subject-centred (Lindmann, 1978).

(5) the resource materials should accommodate learners level of experiencesrather than strictly be developed from formal curriculum (Rogers, 1969).

(6) learning is self-directed rather than teacher-directed (Lindmann, 1978) and that

(7) learners should be led to explate their own resources through the use of the multitude of tcchniques, such is discussion, rolc-playing, case methods, etc. (Knowles, 1980).

(8) he/she accepts both the intellectual content and the emotional attitude of learners (Rogers, 1969).

(9) learners must have constant feedback about the attainment of goals (Gibb, 1960).

(10) learners should be active participants rather than passive listeners or viewers (Hilgard and Bower, 1966; Rogers, 1969).

(11) the instructor should encourage student-student interaction as opposed to student-teacher interaction (Bruner, 1966).

(12) self-evaluation by learners is to be encouraged (Knowles, 1980 )

(13) the instructor should involve learners in developing mutually acceptable criterta for measuring progress toward the learning objectives (knowles, 1980).

(14) the learners should hive the opportunity to pilrticipate in the final assessment (Schmidt \& Svenson, 1960).

(15) sclf-ctiticism and self-evaluation are of primary importince and evaluation by others is of secondary importance (Rogers, 1969). 
of university education. There were 32 from the Special Mature program. They averaged about 25 years old, were mostly male, and had grade 12 education.

The sample drawn from the community college was made up as follows: 35 from the Basic Adult education program, 172 from Business courses, 112 from Vocational/Technical stream and 55 from the Nursing program. Those in the Basic Adult Education program were on the average 24 years old, were predominantly female, and had only elementary education. Those attending Business courses were about 20 years old, mostly female and had an average educational background of Grade 12. Those students drawn from the Vocational/Technical and Nursing programs, (112 and 55 respectively) had a similar level of education - high school. However, participants from the Vocational/Technical program were younger (aged 18) and predominantly male while those in Nursing were older (aged 21) and were mainly female.

Analysis. A stepwise discriminant analysis was employed to detect areas of significant differences in both the actual and expected learning experiences of university and community college students. Compatibility between the real and ideal learning experiences in different programs were detected by $\mathrm{t}$-tests. Multiple $\mathrm{t}$-tests were used for assessing the significance of areas of differences in actual and ideal learning experiences across the programs. 3-way ANOVA tests were used for probing the direct as well as the interaction effects of demographic factors, such as sex, age and educational levels, upon such discrepancies.

\section{RESULTS}

Prior to conducting the data analysis, the reliability of the questionnaire was obtained by means of the SPSS Update 7-9 (Hull \& Nie, 1981). The Cronbach coefficient alpha was .81 . The questionnaire was found to have a very high degree of internal consistency.

Are there any discrepancies between the actual and ideal learning experiences on an instructional basis? To answer the basic question, profiles for the university and community college students were developed from the mean scale scores obtained from responses to the 15 aspects of learning experiences (Fig. 1). Strikingly similar patterns were found for each group. However, greater discrepancies between actual and ideal learning conditions were found for the university students than for the community college students.

A subsequent step-wise discriminant analysis of the actual learning experiences between university and community college students showed that the six major areas differentiating students actual learning experiences in two institutions (Table II) were in order of importance: student involvement in final assessment, meeting learners' needs, encouragement of interaction among students, learning climate, instructors' attitudes and instructional techniques. An examination of ideal learning conditions - through another discriminant analysis - indicated that the desire for involvement in the final assessment was also the most important factor discriminating between the responses of the university and community college 
MEAN SCALE SCORES

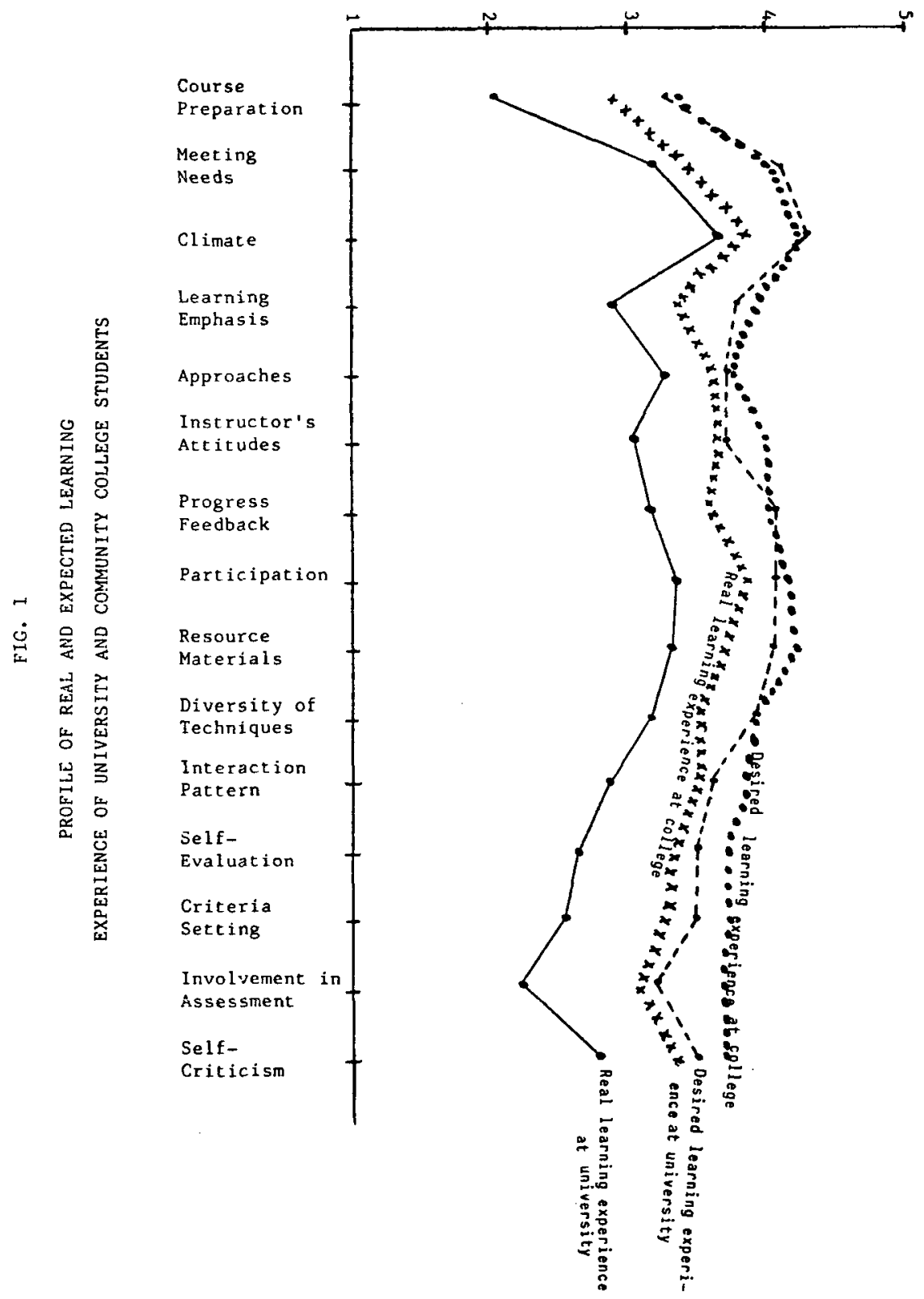


TABLE II

STEPWISE DISCRIMINANT ANALYSIS OF FACTORS

DIFFERENTIATING REAL AND DESIRED UNIVERSITY AND COMMUNITY LEARNING EXPERIENCES

\begin{tabular}{|c|c|c|c|c|c|c|c|c|}
\hline \multirow[b]{2}{*}{ FACTOR } & \multirow{2}{*}{\multicolumn{2}{|c|}{$\overline{\mathrm{x}}$}} & \multicolumn{4}{|c|}{ Real Learning Experiences } & \multirow[b]{2}{*}{$\begin{array}{r}\text { Change in } \\
\text { Rao's V }\end{array}$} & \multirow[b]{2}{*}{ Sig. } \\
\hline & & & \multicolumn{2}{|c|}{ s.d. } & $\begin{array}{l}\text { Order of } \\
\text { Entry }\end{array}$ & $\begin{array}{l}\text { Wilks' } \\
\text { Lambda }\end{array}$ & & \\
\hline $\begin{array}{l}\text { Student Involvement in Final } \\
\text { Assessment }\end{array}$ & 2.89 & 2.28 & 1.26 & 1.16 & 1 & .94 & 45.94 & .000 \\
\hline $\begin{array}{l}\text { Mecting Learners' Needs Ex- } \\
\text { periences and Interest }\end{array}$ & 3.67 & 3.23 & .92 & .99 & 2 & .91 & 22.39 & .000 \\
\hline $\begin{array}{l}\text { Encouragement of Interactions } \\
\text { Among Students }\end{array}$ & 3.38 & 2.86 & 1.05 & 1.10 & 3 & .89 & 14.63 & .000 \\
\hline $\begin{array}{l}\text { Learning Climate: Open, } \\
\text { Murual Trust and Respect }\end{array}$ & 3.80 & 3.71 & 1.05 & .97 & 4 & .89 & 5.49 & .019 \\
\hline $\begin{array}{l}\text { Acceptance of Learners' } \\
\text { Intellects and Atcitude }\end{array}$ & 3.49 & 3.04 & 1.08 & 1.05 & 5 & .88 & 8.26 & .004 \\
\hline $\begin{array}{l}\text { Exposure to Different Class- } \\
\text { room Techniques }\end{array}$ & 3.48 & 3.00 & 1.08 & 1.13 & 6 & .87 & 5.68 & .017 \\
\hline & & & ed Le & ing Ex & ences & & & \\
\hline $\begin{array}{l}\text { Student Involvement in } \\
\text { Final Assessment }\end{array}$ & 3.59 & 3.33 & 1.17 & 1.11 & 1 & .98 & 9.50 & .002 \\
\hline $\begin{array}{l}\text { Constant Feedback About } \\
\text { Progress in Study }\end{array}$ & 4.02 & 4.19 & 1.12 & .81 & 2 & .97 & 10.17 & .001 \\
\hline $\begin{array}{l}\text { Participation in All } \\
\text { Learning Sessions }\end{array}$ & 4.17 & 4.08 & .99 & .79 & 3 & .96 & 5.18 & .022 \\
\hline Self-directing Learning & 3.67 & 3.77 & 1.18 & .97 & 4 & .96 & 4.43 & .035 \\
\hline $\begin{array}{l}\text { Acceptance of Learners' } \\
\text { Intellects and Attitude }\end{array}$ & 3.96 & 3.84 & 1.07 & 1.01 & 5 & .95 & 3.00 & .082 (N.S.) \\
\hline $\begin{array}{l}\text { Learning Climate: Open, } \\
\text { Mutual Trust and Respect }\end{array}$ & 4.26 & 4.36 & 1.09 & .78 & 6 & .95 & 3.72 & .050 \\
\hline
\end{tabular}

Progress in Study

articipation in $A l$

\begin{abstract}
$3.59 \quad 3.33$
$4.17 \quad 4.08$

$67 \quad 3.77$

$4.26 \quad 4.36$
\end{abstract}


students. Desire for feedback, participation, learning emphasis, instructor's attitude and climate followed in that order.

In view of the fact that such institutional differences might be attributed to program differences, two separate analyses were undertaken: one addressed to the "compatibility" of the real and the desired learning experiences within each program (Table III), the other to a comparison of discrepancies, if any, among all programs examined (Table IV).

The analyses of the within-program discrepancies revealed that, in the community college, students in the basic adult education generally did not feel incompatibility between the real and desired learning experiences. In contrast, in business education, the real and the ideal learning experiences were significantly different in every aspect. With the exception of climate, instructional approaches and participation in the learning process, real and ideal learning experiences of those enrolled in the Vocational/Technical program again differed markedly. For those in the Nursing program, discrepancies were again found except in the area of instructional approaches.

University students in Arts, Science and Music programs, all declared significant discrepancies in each of the fifteen aspects of learning experiences. In the case of Education students, such discrepancies were found in all except instructional approaches. Students from Non-Credit courses noted incompatibility in all except instructional approaches and attitudes of instructors. Students in the Special Mature program reported compatibility in the climate, the learning emphasis, instructional approaches, attitude of instructors and diversity of techniques employed.

Multiple (t-test) comparisons across the programs (Table IV) revealed substantial differences in learning experiences in terms of the 15 aspects of andragogical principles. In terms of the real learning experiences, students in the Basic Adult program had significantly different learning experiences from those in Business, Arts, Education, Music, Non-Credit and Special Mature programs. Those students in the Business program perceived their experiences to be much different from students in Vocational/Technical, Nursing, Arts, and Special Mature programs. The responses of Vocational/Technical students denoted significant characteristic differences in learning experiences from Arts, Education, Non-Credit and Special Mature students. Arts students found their experiences differed significantly from Science and Special Mature students. Education, Science and Music students had different learning experiences compared to their Special Mature counterparts. When ideal learning experiences were examined, however, no major differences in terms of the desired learning experiences of the participants were found between programs other than the fact that the responses of students in the Nursing program indicated student nurses did entertain expectations somewhat different from Science and Special Mature students.

Can a portion of the detected program differences be accounted for by individual factors? A three-way analysis was undertaken to assess the varying degree of 
TABLE III

COMPATIBILITY BETWEEN RFAL AND IDEAL LEARNING CONDITIONS

AS PERCE IVEd ay STUdents of Various programs

( $t$-TEST ANALYSES)

\begin{tabular}{|c|c|c|c|c|c|c|c|c|c|c|c|c|c|c|c|c|}
\hline Program & $n$ & $\begin{array}{c}\text { Course } \\
\text { Proparation }\end{array}$ & $\begin{array}{l}\text { Meeting Exp. } \\
\text { Meeds } 6 \text { Interest }\end{array}$ & clinate & $\begin{array}{l}\text { Loarning } \\
\text { Eaphasis }\end{array}$ & $\begin{array}{l}\text { Instructional } \\
\text { Approschios }\end{array}$ & $\begin{array}{l}\text { Attitude } \\
\text { of } \\
\text { Instr. }\end{array}$ & $\begin{array}{c}\text { Feedback } \\
\text { on } \\
\text { Progress }\end{array}$ & $\begin{array}{c}\text { Learners: } \\
\text { Participation }\end{array}$ & $\begin{array}{l}\text { Resource } \\
\text { Materials }\end{array}$ & $\begin{array}{c}\text { Oivorsity } \\
\text { of } \\
\text { Techniques }\end{array}$ & $\begin{array}{c}\text { Interaction } \\
\text { Pattern }\end{array}$ & $\begin{array}{l}\text { Role of } \\
\text { Self-Eval. }\end{array}$ & $\begin{array}{l}\text { Criteris } \\
\text { of } \\
\text { Progress }\end{array}$ & $\begin{array}{l}\text { Invol. in } \\
\text { Final } \\
\text { Eval. }\end{array}$ & $\begin{array}{l}\text { Porc. } \\
\text { of } \\
\text { Solf- } \\
\text { Eval. }\end{array}$ \\
\hline A. C. C. & & & & & & & & & & & & & & & & \\
\hline (i) Basic Adult & 31 & -1.75 & -1.19 & .17 & -1.51 & .49 & -.50 & .36 & 0 & -1.58 & -1.16 & -0.98 & -1.22 & .27 &.- .44 & 0 \\
\hline (ii) Business & 172 & $-13.28=$. & $-10.38 * *$ & $-8.99 * *$ & $-11.83 * *$ & $-3.43 * "$ & $-8.16 " *$ & $-8.22 * *$ & $-7.87 * *$ & $-8.81 * *$ & $-6.49 * n$ & $-5.55 * *$ & $-7.21 * *$ & $-8.82 *$ & $-8.90 * *$ & $-3.21 * *$ \\
\hline $\begin{array}{l}\text { (iii) Vocational- } \\
\text { lechnical }\end{array}$ & 112 & $-5.58 \% *$ & $-2.58 * 4$ & -1.16 & $-3.30 * *$ & -1.28 & $-2.32=$ & $-4.12 n=$ & -1.13 & $-4.28=4$ & $-4.00=*$ & $-2.2 \theta^{\circ}$ & $-3.06 \cdot$. & $-3.81 \ldots$ & $-4.01 \cdots$ & $-3.37 \%$ \\
\hline (iv) Nursing & 55 & $-10.55 *$ & $-5.46 \cdots$ & -6.7800 & $-4.56 * 0$ & .95 & $.6 .11 * *$ & $-5.09 \cdot *$ & $-3.97 n$ & $-6.05 * n$ & -4.1600 & $-3.15^{* *}$ & $-2.87 \ldots$ & $-5.10=$ & $-5.780 . *$ & $-3.35 * *$ \\
\hline UMTYERSIIY & & & & & & & & & & & & & . & & & \\
\hline (i) Arts & 142 & $-12.12+4$ & $-11,09 * *$ & $-6.79 * *$ & $-8.24 * *$ & $-3.45 *$ & $-11.65 * *$ & $-11.43 * *$ & $-11.15 * *$ & $-9.74 \%$ & $-12.02 * *$ & $-11.50 * *$ & $-8.83 * *$ & $-12.72+$ & $-11.05=0$ & $-9.27 \cdots$ \\
\hline (ii) Education & 84 & $-10.71 * *$ & $-7.85 \mathrm{kH}$ & $-6.75 *$ & $-9.23 *$ & -1.78 & $-5.93 * *$ & $-6.65 \%$ & $-5.07 *$ & $-5.62 * *$ & $-6.81 \cdots$ & $-6.10^{* 0}$ & $-5.76 \mathrm{*m}$ & $-9.37 *$ & -7.2790 & $-6.38 * n$ \\
\hline (iii) Science & 50 & $-11.94 \ldots$ & i $\quad-8.85^{* * *}$ & $-5.75 * *$ & $-9.03 * *$ & $-4.59 * *$ & $-6.03 * *$ & $-8.12 \%$ & $-6.78 * *$ & $-6.95 * *$ & $-5.99 \%$ & $-5.86 * *$ & $-9.06 * *$ & $-11,30^{* * *}$ & $-6.66 * *$ & $-7.16 * *$ \\
\hline (iv) Music & 31 & $-5.43 * t$ & $-4.25 * *$ & $-3.15 * *$ & $-6.19 * *$ & $-4.73 * *$ & $-5.42 * *$ & $-4.590 \%$ & $-4.76 m$ & $-3.59=*$ & $-3.72 * *$ & $-5.00^{* *}$ & $-4.93 n *$ & $-6.83^{* *}$ & $-4.90 * *$ & $-7.01 * *$ \\
\hline (v) Nan-Credit & 32 & $-6.45 * *$ & $-2.60 * *$ & $-3.70 * *$ & $-2.96 * *$ & -.57 & 1.65 & -3.4000 & $-2.83 * *$ & $-3.69 * *$ & $-3.38=*$ & $-2.66 * 0$ & $-2.51 * *$ & $-3.77 * *$ & $-4.64 * *$ & $-3.43 \cdots$ \\
\hline $\begin{array}{l}\text { (vi) Special } \\
\text { Mature }\end{array}$ & 32 & $-3.21 * *$ & $-3.62=0$ & -1.31 & -.90 & -.64 & -1.65 & $-3.74 n *$ & $-3.13=$ & $-3.00 * \hbar$ & -1.76 & $-2.67 * *$ & -3.7600 & $\begin{array}{l}-3.00=0 \\
\backslash\end{array}$ & $-2.47 * *$ & $-2.36 *$ \\
\hline
\end{tabular}




\begin{tabular}{|c|c|c|c|c|c|c|c|c|c|c|}
\hline \multicolumn{11}{|c|}{ Real Learning Experiences } \\
\hline & & Business & $\begin{array}{l}\text { Vocational } \\
\text { Technical }\end{array}$ & Nursing & Art & Education & Science & Music & $\begin{array}{l}\text { Non- } \\
\text { Credit }\end{array}$ & $\begin{array}{l}\text { Special } \\
\text { Mature }\end{array}$ \\
\hline (I) & Basic Adult & $2.60^{*}$ & 1.20 & .52 & $3.85 * \pi \hbar$ & $2.95 * *$ & 1.95 & $2.42 \pi *$ & $3.52 * * *$ & $4.84 * \pi *$ \\
\hline (II) & Business & & $-2.25 *$ & $-2.66 * *$ & $2.27 *$ & .76 & -.43 & .55 & 1.89 & $3.63 * \star \star$ \\
\hline (III) & $\begin{array}{l}\text { Vocational } \\
\text { Technical }\end{array}$ & & & -.81 & $4.33^{* * *}$ & $2.64 \star \star$ & 1.17 & 1.90 & $3.15 * *$ & $4.80 * * *$ \\
\hline (IV) & Nursing & & & & $4.06 \div \div$ & $2.94 * \star$ & 1.65 & $2.21 *$ & $3.45 * \frac{1}{4} *$ & $4.95 * * *$ \\
\hline (v) & Art & & & & & -1.15 & $-2.00 *$ & -.70 & .55 & $2.20^{*}$ \\
\hline$(V I)$ & Education & & & & & & -.94 & .04 & 1.23 & $2.80 * *$ \\
\hline (VII) & Science & & & & & & & .78 & 1.86 & $3.30 * \pi \star$ \\
\hline (VIII) & Music & & & & & & & & 1.00 & $2.30 *$ \\
\hline \multirow[t]{11}{*}{$(\mathrm{IX})$} & Non-Credit & & & & & & & & & 1.32 \\
\hline & & & & ired Lear & ing Exper & aces & & & & \\
\hline & Basic Adult & -.25 & .47 & -1.27 & -1.87 & -.23 & 1.37 & .57 & -.33 & 1.23 \\
\hline & Business & & .80 & -1.46 & .11 & 0 & 2.07 & 1.00 & .18 & 1.87 \\
\hline & $\begin{array}{l}\text { Vocational } \\
\text { Technical }\end{array}$ & & & -2.07 & -.70 & -.72 & 1.36 & .47 & -.68 & 1.37 \\
\hline & Nursing & & & & 1.53 & 1.35 & $2.87 * *$ & 1.94 & .88 & $2.72 \star \star$ \\
\hline & Arts & & & & & -.09 & 2.00 & .93 & .25 & 1.81 \\
\hline & Education & & & & & & 1.92 & .94 & -.17 & 1.76 \\
\hline & Science & & & & & & & -.57 & -1.66 & .16 \\
\hline & Music & & & & & & & & -.90 & .66 \\
\hline & Non-Credit & & & & & & & & & 1.65 \\
\hline
\end{tabular}


impact, age, sex, and formal education had upon the perceived discrepancies between the real and expected learning experiences. In sum, sex was found to relate to the discrepancies in meeting learners' needs $(F=3.81, \rho<.05)$ and learning climate $(F=7.34, \rho<.01)$. Age was found to relate to perceived discrepancies in participation $(F=4.67, \rho<.05)$, resource material $(F=3.90$, $\rho<.05)$ and in importance of self-criticism $(F=4.08, \rho<.05)$. Level of formal education was associated with discrepancies in learning emphasis $(\mathrm{F}=3.91, \rho<$ $.05)$, progress feedback $(F=6.58, \rho<.01)$, self-evaluation $(F=9.73, \rho<.01)$, involvement in the development of criteria $(F=8.62, \rho<.01)$ and overall assessment $(\mathrm{F}=8.09, \rho<.01)$ as well as recognizing the role of self-criticism in evaluation $(F=5.43, \rho<.01)$.

Two and three way interactions further highlight the intricate relationship of these factors with the aspects already identified as having significant incompatibility.

Of interest, discrepancies in learning climate was attributed to the interaction between age and formal education $(F=11.58, \rho<.01)$, discrepancies in the teaching approach was related to the interaction effects between sex and age $(\mathrm{F}=$ $4.90, \rho<.05)$ or formal education $(F=4.12, \rho<.05)$. Discrepancies in program feedback, diversity of techniques and assessment criteria were the results of interaction among sex, age and formal education respectively $(\mathrm{F}=6.94, \rho<.01$; $F=4.09, \rho<.05 ; F=3.91, \rho<.05)$. And discrepancies in the importance of self-criticism as the assessment could be associated with the interaction of sex and age $(F=4.43, \rho<.05)$, sex and formal education $(F=6.20, \rho<.01)$ and threeway interaction among sex and age and formal education $(F=4.99, \rho<.05)$.

What is obtained explicitly from the cross-tabulation is the observation that the more educated, older students were more demanding that their learning experiences be in agreement with the stated andragogical principles. In addition, female students were more concerned that the course content as well as the general setting and climate under which learning takes place meet their needs.

\section{DISCUSSION}

Given the varying degree of learning experience differences both between institutions and among programs, one is impressed with the strikingly similar discrepancies between the real learning experiences and the ideal (outlined by the principles of andragogy) both at the university and community college. One might quickly associate this difference with the fact that the traditional subject-centred approach is still the predominant mode of instruction at the postsecondary institution. However, if the traditional class or lecture had been shown empirically to be the one learning method most preferred and most used in education (e.g. Darkenwald \& Merriam, 1982; Oddi, 1983) and if a well structured instructional approach were equally satisfactory to learners (Rosenblum \& Darkenwald, 1983), one should not expect the gap between real and the ideal experiences to be so 
marked. A more thorough search of the factors for contributing to such a phenomenon seems to be in order.

That the types of institutions should constitute a major factor for explaining the learning experience differences is not a surprise. Bleyer and Middleton (1979) reported marked attitudinal differences among students of various types of postsecondary institutions, as individuals with different personalities tended to attend specific types of institutions. It would seem logical first to attribute learning experience differences to some perceptual differences among different types of students at the two institutions.

However, in terms of the ideal (or desired) learning experiences, very few differences were detected. This fact clearly indicates that despite different personalities, students' expectations at both the university and the college are sufficiently similar to reject attitude as a basic factor for the declared learning experience differences. Rather, it is more than clear that the way various programs are delivered constitutes the major institutional difference with respect to learning experience for the learner.

Further, in view of the fact that individuals who undertake different programs vary greatly in sex, age and formal education, the present study in a real sense confirms findings of others, notably Brainard and Ommen (1977), Hunter and McCantz (1977), that sex and age are important factors affecting perception of learning experiences. Female learners are more concerned that courses be designed to meet their specific background and interest and they are more sensitive to the type of learning climate. More mature students favor higher participation in all learning sessions, feel that the resource materials utilized should be at their level of experience and that self-criticism should play a role in the evaluation process.

Most critical to the learners' expectations of study experience but least reported in adult literature is the fact that the formal education level of the adults accounts for far more discrepancies in far more aspects than those accounted for by sex and age combined. From the present data, adults with higher educational background demand that learning should be more life-centred and less subject-centred. They expect constant feedback about their progress. They value self-evaluation as part of the overall assessment of their performance. They wish to be more involved in developing criteria for assessment. They demand a greater voice in formulating the final assessment format and they consider self-criticism to be of primary importance. The significance of the formal educational level of participants is registered clearly in the comparison of learning experiences across programs. Adults in Basic Education of the community college and the Special Mature program of the university who have far fewer years of formal education display a higher degree of compliance with the existing teacher-structured instructional modes, and less with those propounded by the andragogical principles.

The complexity of adult learners' preference in the styles of teaching and learning is highlighted by the discrepancies due to the interaction effects of these individual factors. In general, male learners with lower formal education preferred 
a far more structured learning context in terms of climate, feedback, approach, and assessment than are specified by andragogical principles. Older students, on the other hand, are among those who are mostly concerned with non-threatening teaching style, with constant feedback and the emphasis of self-criticism as part of the assessment process. What emanated from their responses is a need for reassurance to substain self-confidence in the entire teaching/learning process.

In retrospect, the present findings tend to provide some critical linkages between higher education and adult education, which for some unknown reason are seldom integrated. It is evident that while the general principles of andragogy are very much desired by learners, as reflected by the ideal learning condition defined in the present context, the data examined here fall short of full endorsement. The majority of adult learners express a desire for more but not complete partnership in the planning, organizing, delivery and evaluating of courses. The basic premise of the learner-centred approach proposed by the principles of andragogy rests a great deal on the cognitive maturity of adult learners. Where adult learners are deficient in formal education, and are operating in what Perry termed "dualistic mode" (1970), they prefer a learning style and environment more structured than those who are more sophisticated and operate on "relativistic position". Indeed much has been written (eg., Snelbecker, 1974; Mann, 1970; Parker, 1978) about exploring diverse instructional strategies in assisting these two different categories of adults to learn. Adult instructors at the postsecondary institutions should take heed of the suggestions and be prepared to modify their current approaches if they wish to make learning more satisfactory to their learners.

On the other hand, unless the principles of andragogy are designed to take cognizance of intellectual abilities and learning orientation, they will fail as practical guidelines for maximizing meaningful learning for most adults.

\section{REFERENCES}

Bleyer, D. \& Middleton, D. "An attitudinal study of students in a community college, a state university and a technical institute". Community Junior College Research Quarterly, 1979, $3(2), 129-137$.

Brainard, S. \& Ommen, J. Men, women and learning styles. Community College Frontiers, 1977, $5(3), 32-36$.

Bruner, J.S. Toward a theory of instruction. Cambridge, Mass.: Harvard University Press, 1966.

Carlson, R.A. "The time of andragogy". Adult Education, 1979, 30(1), 53-57.

Cole, J. \& Glass, J.C. The effect of adult student participation in program planning on achievement retention and attitude. Adult Education, 1977, 27(2), 75-88.

Cross, K.P. Adults as learners. San Francisco: Jossey-Bass, 1981, 222-228.

Darkenwald, G.G. \& Merriam, S.R. Adult education: foundations of practice. New York: Harper \& Row, 1982.

Elias, J.L. "Andragogy revisited. Adult Education, 1979, 29(4), 252-

Gage, N.L. Teacher effectiveness and teacher education. Palo Alto, Calif.: Pacific Books, 1972.

Gibb, J.R. "Learning theory in adult education". in M.S. Knowles (ed.). Handbook of Adult Education in the United States. Chicago: Adult Association of U.S.A., 1960, 54-64. 
Hilgard, E.R. \& Bower, G.H. Theories of learning. New York: Appleton-Century-Crofts, 1966.

Houle, C.O. The inquiring mind. Madison: University of Wisconsin Press, 1961.

Hull, C.H. \& Nie, N.H. (ed.). SPSS Update 7-9. New York: McGraw-Hill, 1981, 248-267.

Hunter, W.E. \& McCantz, L.S. The new generation gap: involvement vs. instant information. ERIC Clearing House for Junior Colleges, 1977, Topical Paper No. 64.

Kidd, J.R. How adults learn. New York: Association Press, 1959.

Knowles, M.S. Informal adult education. New York: Association Press, 1950.

Knowles, M.S. The adult learner: a neglected species. (2nd ed.). Houston: Gulf Publishing Co., 1978.

Knowles, M.S. The modern practice of adult education. (rev. ed.). Chicago: Association Press, 1980.

Lam, Y.L.J. Selected course content, cognitive and affective factors and classroom behaviors of adult learners. British Journal of Educational Psychology, 1982, 52(3), 350-360.

Lindmann, E.C. The meaning of adult education. New York: New Republic, 1926.

London, J. "Program development in adult education" in M.S. Knowles, (ed.). Handbook of Adult Education in the United States, Chicago: AEA of the U.S.A., 1960, 65-81.

Mann, R.D. et al. The college classroom: conflict change and learning. New York: Wiley, 1970.

McKenzie, L. "The issue of andragogy". Adult Education, 1977, 27(4), 225-229.

Oddi, C. "The lecture: an update on research". Adult Education, 1983, 33(4), 222-229.

Parker, C.A. (ed.). Encouraging developments in college students. Minneapolis: University of Minnesota Press, 1978.

Perry, W.J. Forms of intellectual and ethical development in the college years. New York: Holt, Rinehart and Winston, 1970.

Rogers, C.R. Freedom to learn. Columbus, Ohio: Merrill, 1969.

Rosenblum, S. \& Darkenwald, G.G. "Effects of adult learner participation in course planning on achievement and satisfaction". Adult Education, 1983, 33(3), 147-152.

Schmidt, W.H. \& Svenson, E.V. "Methods in adult education", in M.S. Knowles. Handbook of Adult Education in the United States. AEA of U.S.A., Chicago, 1960, 82-95.

Snelbecker, G. Learning theory, instructional theory and psychoeducational design. New York: McGraw-Hill, 1974. 